\title{
From numbers to ecosystems and biodiversity: A mechanistic approach to monitoring
}

\author{
Authors: \\ Sam Ferreira ${ }^{1}$ \\ Andrew Deacon ${ }^{1}$ \\ Hendrik Sithole ${ }^{1}$ \\ Hugo Bezuidenhout ${ }^{2}$ \\ Mahlomola Daemane ${ }^{2}$ \\ Marna Herbst ${ }^{2}$ \\ Affiliations: \\ ${ }^{1}$ Savanna Research Unit, \\ South African National Parks, \\ Skukuza, South Africa \\ ${ }^{2}$ Arid Research Unit, South \\ African National Parks, \\ Kimberley, South Africa \\ Correspondence to: \\ Sam Ferreira

\section{Email:} \\ Sam.Ferreira@sanparks.org \\ Postal address: \\ Private Bag X402, Skukuza \\ 1350 , South Africa \\ Dates: \\ Received: 18 Apr. 2010 \\ Accepted: 02 Feb. 2011 \\ Published: 13 May 2011 \\ How to cite this article: \\ Ferreira, S., Deacon, A., \\ Sithole, H., Bezuidenhout, \\ H., Daemane, M. \& Herbst, \\ M., 2011, 'From numbers to \\ ecosystems and biodiversity: \\ A mechanistic approach \\ to monitoring', Koedoe \\ 53(2), Art. \#998, 12 pages. \\ doi:10.4102/koedoe. \\ v53i2.998
}

\section{2011. The Authors.} Licensee: OpenJournals Publishing. This work is licensed under the Creative Commons Attribution License.
Diverse political, cultural and biological needs epitomise the contrasting demands impacting on the mandate of the South African National Parks (SANParks) to maintain biological diversity. Systems-based approaches and strategic adaptive management (learn by doing) enable SANParks to accommodate these demands. However, such a management strategy creates new information needs, which require an appropriate analytical approach. We use conceptual links between objectives, indicators, mechanisms and modulators to identify key concerns in the context of and related to management objectives. Although our suggested monitoring designs are based mostly on defined or predicted underlying mechanisms of a concern, SANParks requires inventory monitoring to evaluate its key mandate. We therefore propose a predictive inventory approach based on species assemblages related to habitat preferences. Inventories alone may not always adequately serve unpacking of mechanisms: in some cases population size needs to be estimated to meet the information needs of management strategies, but actual population sizes may indirectly affect how the species impact on other values. In addition, ecosystem objectives require multivariate assessments of key communities, which can be used in trend analysis. SANParks therefore needs to know how to detect and define trends efficiently, which, in turn, requires precision of measures of variables.

Conservation implications: Current research needs with regard to monitoring should focus on defining designs to yield optimal precision whilst taking methodology, survey trade-offs and analytical approaches into account. Use of these directives and research will guide monitoring during evaluation of SANParks objectives at various scales.

\section{Introduction}

Monitoring the performance of protected areas on several scales is a common conservation challenge worldwide (Noss 1990; Noon, Spies \& Raphael 1999; Possingham et al. 2001; Woodroffe \& Ginsberg 1998) and has been met with some success (Bruner et al. 2001; Knight et al. 2006; Salafsky \& Margoluis 1999) and some failure (Curran et al. 2004; Liu et al. 2001). In many instances, monitoring the performance of conservation agencies with regard to achieving their key mandate of maintaining biodiversity has been, at best, haphazard in the past (McGeogh et al. 2011). This may stem from (1) mechanisms (i.e. the biological effects of a factor and modulators in the system) being poorly defined, which may threaten conservationists' achieving objectives, (2) ill-defined or nonexisting objectives of monitoring plans, (3) uncertainties regarding indicators (i.e. biological indicators of specific environmental conditions) and measurement parameters to address specific objectives, and (4) uncertainties and disagreements regarding measurement of response as well as explanatory variables (Lindenmayer \& Likens 2009).

In addition to nonrobust approaches to monitoring, political, cultural and religious beliefs influence conservation approaches (Brandon, Redford \& Sanderson 1998; Doyle \& McEachern 2008; Lawton 1997; Martello 2001). These contrasting demands force modern-day conservationists to embrace complexity as a leading value to recognise the social, economic and ecological interactions that epitomise cultural, historical and natural heritage (Bruner et al. 2001; Ghimire \& Pimbert 1997; Scoones 1999). In such instances conservationists are vulnerable to effects of shifting conceptual approaches (e.g. Lewis 1996; Lindenmayer \& Likens 2009; Morellet et al. 2007) that create confusion or direct conservation management into areas that have not been scientifically defined yet. The recognition of complexity requires a management style based on a systems approach (Brussard, Reed \& Tracy 1998; Brandon et al. 2005; De Leo \& Levin 1997; Kay \& Schneider 1994). For example, because of the complexity of biodiversity, surrogates such as subsets of species, species assemblages and habitat types were proposed as measures of biodiversity. The locations of these surrogates within areas have to be plotted to allow an estimated comparison between the areas (Margules \& Pressey 2000). Whether correct or not, such styles impose information needs that exceed the traditional requirements on which conservationists base management decisions. 
Ecosystem management is a topical systems paradigm (Bocking 1994). The approach can allow for appropriate management of biological diversity of ecosystems, species and genetic resources - the primary mandate of conservation agencies - within the constraints of tourist, stakeholder and economic expectations (Lindenmayer, Franklin \& Fischer 2006; McNeely 1994; Slocombe 1998). Ecosystem management involves two essential elements, namely integration of scientific knowledge and maintenance of evolutionary potential (Bocking 1994; Parrish, Braun \& Unnasch 2003; Rodrigues et al. 2004; Sale et al. 2005; Simberloff 1999). The latter focuses on facilitating, maintaining or restoring ecological processes (e.g. Wassenaar et al. 2005; Wassenaar, Ferreira \& Van Aarde 2007). This can be addressed, to a large extent, by strategic adaptive management approaches (Biggs \& Rogers 2003; Tompkins \& Adger 2004): conservationists use knowledge of a system's underlying mechanisms to develop a management strategy that predicts relevant system responses, robustly assess the outcomes, and then adapt management actions accordingly if needed (Rogers 1997).

Protected areas are seldom pristine (McNeely 1994). They are either limited owing to features that impede spatial and temporal variability in ecological processes (e.g. Du Toit, Rogers \& Biggs 2003) or degraded owing to a history of disturbed ecological processes often due to agricultural activity (Agardi 2000; Braaz 1992; Noss 1999). This challenges traditional monitoring programmes directed at supporting management decisions focused on species (e.g. Regan et al. 2008) and to some extent future monitoring may still have such a focus. In addition, only restorative actions can attempt to maintain evolutionary potential when large sections of the biota are locally extinct and/or have been replaced by exotic organisms (e.g. Wassenaar et al. 2005), but this requires very different measures or interpretation of existing approaches.

In this paper we provide a conceptual framework for defining monitoring parameters. We first establish the context specific to South African National Parks (SANParks), especially as it pertains to adaptive management. We then challenge the static nature of thresholds of potential concern as applied at present and suggest a revised approach that flags potential ecosystem degradation through the development of a mechanisms-based unpacking of an ecological concern. The approach allows us to illustrate how information needs, albeit diverse, can have a common strategic design.

\section{The SANParks context}

Biological diversity results from a variety of processes and interactions on ecological and evolutionary time scales (Wilson 1988). Human activities and the organisms that travel with them (animal pests and weeds) have changed biological processes throughout the world (Chapin et al. 2000; Daszak, Cunningham \& Hyatt 2000) and are collectively referred to as human-induced disturbance. A systems-based approach to improving the capacity of SANParks to achieve its key mandate requires the management of human-induced disturbances. According to such an approach management should view ecosystem problems as components of an overall system and therefore not act only on specific aspects, outcomes or events in order to reduce the contribution to unintended consequences (Ackoff 2010).

The key mandate of SANParks requires conservationists to maintain biological diversity within its jurisdiction (Knight 2007; Varghese 2008). SANParks therefore has two primary needs to evaluate whether it is achieving its mandate, namely determining species status and ecosystem health within the parks. Determining species status within SANParks is particularly important with reference to rare species defined as not abundant or only locally abundant (Gaston 2008; Preston 1948). Evaluating conservation outcomes for such species when using traditional approaches to define population trends is challenging (McArdle 1990). Measuring rare species, however, may not reflect much on ecosystem dynamics (Gaston 2008; Smith \& Knapp 2003), despite important contributions to them. The wellness of ecosystems can be assessed by considering less common species, which act as keystone species, augment efficacy (e.g. invasion resistance) of the community and/or play critical roles in ecosystem resilience (Lyons et al. 2005). These measurements require multivariate approaches and techniques that have been applied only to a limited extent in the conservation and restoration environment (Spellerberg 2005).

SANParks uses thresholds of potential concerns (TPCs) to define a range of possible states for species populations or ecosystems (see Biggs \& Rogers 2003; Foxcroft 2009). This approach presents challenges because it requires definition of these states (e.g. Milton et al. 1994), a process which is not formally established in the SANParks planning environment. In addition, the TPC approach requires various types of information, for example a definition of (1) species diversity, (2) population size, (3) temporal and/or spatial changes in populations and (4) an assessment of whether such changes are within the (established or predicted) TPC. Several species-focused TPCs were defined for the Kruger National Park in 2002 (Table 1), but few of these have been addressed since the inception of this approach. At the time, the Largescale Herbivore and Fire Interaction Research Experiment (LASHFIRE) programme was about to be launched (Trollope et al. 1999) and elements of the programme were built into most of the research and monitoring of TPCs.

After the suspension of the LASHFIRE programme, speciesfocused monitoring, particularly of small vertebrates, was implemented in pilot studies of different vegetation types. However, during drafting the 2007 TCPs (South African National Parks 2007), the approach was used extensively to describe the concept of homogenisation, which was considered as a loss of dissimilarity (Table 2). The purpose was to create an indicator of system function and associated biodiversity. However, these were never fully implemented owing to the intense and cumbersome monitoring required.

Many of the constraints with regard to implementation of TPCs stem from prioritisation and evaluation uncertainty. 
A conceptual approach that links objectives, indicators, mechanisms and modulators in an effort to identify key concerns in the context of management objectives (Gaylard \& Ferreira 2011) and a range of states and transitions (Westoby, Walker \& Noy-Meir 1989; Rietkerk \& Van de Koppel 1997) can greatly assist in the development of appropriate, focused and robust monitoring plans. In such instances, monitoring designs should be based on defined or predicted underlying mechanisms of a conservation concern.

However, SANParks also requires inventory monitoring to evaluate its key mandate (Biggs \& Rogers 2003). In this case a conceptual approach should use predictive inventory techniques (i.e. evaluations of observed versus predicted species presence), because few species lend themselves to easy estimation of abundance (Regan et al. 2008). In several cases, though, species such as large herbivores (e.g. Kruger, Reilly \& Whyte 2008) do lend themselves to estimation of numbers. Management may require such information when population sizes may indirectly affect how a species impact on other values (SANParks 2010), given that spatial mechanisms, rather than abundance, are primary drivers of large mammal effects on ecosystems (Van Aarde, Jackson \& Ferreira 2006). In addition, evaluating ecosystem objectives require multivariate assessments of key communities (Wassenaar et al. 2007). Nearly all measurement types and SANParks objectives require trend analysis to allow efficient detection and definition of trends. This requires precision

TABLE 1: Thresholds of potential concern, with a species focus, as constructed for the Kruger National Park in 2002.

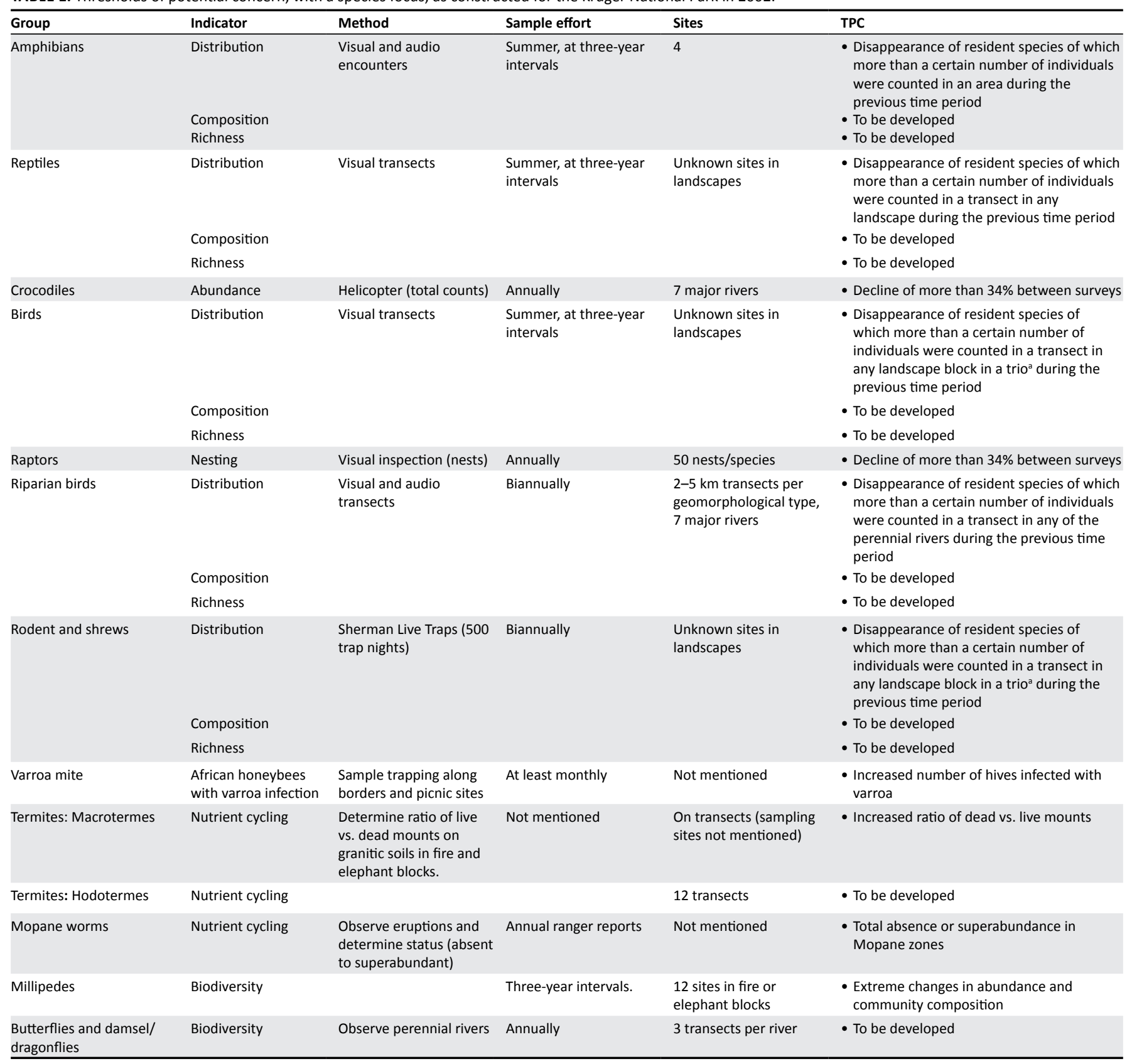

TPC, thresholds of potential concern.

a, refers to terms used in the LASHFIRE programme; detail is available from SANParks. 
TABLE 2: Thresholds of potential concern, with a species focus or components with a species focus, as revised for the Kruger National Park in 2007. ${ }^{\text {a }}$

\begin{tabular}{|c|c|c|c|c|c|}
\hline Group & Indicator & Method & Effort & Sites & TPC \\
\hline \multirow[t]{5}{*}{ threatened species } & wild dog & to be determined & to be determined & park wide & $\begin{array}{l}\text { - population declines to fewer than } 12 \text { packs } \\
\text { - median pack size } \leq 6\end{array}$ \\
\hline & black rhino & to be determined & to be determined & park wide & $\begin{array}{l}\text { - no increase in population growth rate } \\
\text { between two surveys }\end{array}$ \\
\hline & $\begin{array}{l}\text { critically endangered } \\
\text { plants }\end{array}$ & to be determined & to be determined & park wide & $\begin{array}{l}\text { - } \geq 5 \% \text { decrease in the population between any } \\
\text { two surveys } \\
\text { - skewed population size or age classes, with } \\
\text { little or no sign of normalisation for } \leq 3 \text { years } \\
\text { - decline of } 5 \% \text { in geographic distribution of } \\
\text { subpopulations } \\
\text { - detrimental effect on regeneration that } \\
\text { affects } \geq 5 \% \text { of reproductive individuals }\end{array}$ \\
\hline & endangered plants & to be determined & to be determined & park wide & $\begin{array}{l}\text { - } \geq 10 \% \text { decrease in the population between } \\
\text { any two surveys } \\
\text { - skewed population size/age classes, with } \\
\text { little or no sign of normalisation for } \leq 4 \text { years } \\
\text { - decline of } 10 \% \text { in geographic distribution of } \\
\text { subpopulations } \\
\text { - detrimental effect on regeneration that } \\
\text { affects } \geq 10 \% \text { of reproductive individuals }\end{array}$ \\
\hline & vulnerable plants & to be determined & to be determined & park wide & $\begin{array}{l}\text { - } \geq 15 \% \text { decrease in the population between } \\
\text { any two surveys } \\
\text { - skewed population size/age classes, with } \\
\text { little or no sign of normalisation for } \leq 5 \text { years } \\
\text { - decline of } 15 \% \text { in geographic distribution of } \\
\text { subpopulations } \\
\text { - detrimental effect on regeneration that } \\
\text { affects } \geq 15 \% \text { of reproductive individuals }\end{array}$ \\
\hline \multirow[t]{2}{*}{ heterogeneity } & woody structure & $\begin{array}{l}\text { vegetation component } \\
\text { analyses and remote sensing }\end{array}$ & to be determined & $\begin{array}{l}\text { extensive and intensive } \\
\text { monitoring sites }\end{array}$ & - failure of woody structure component \\
\hline & weighted heterogeneity ${ }^{b}$ & several techniques & to be determined & $\begin{array}{l}\text { sensitive zone } \\
\text { land system } \\
\text { land type } \\
\text { terrain unit }\end{array}$ & - weighted score $<20$ \\
\hline
\end{tabular}

TPC, thresholds of potential concern.

a, detail is available from SANParks.

$b$, the weighted score refers to data layers that include woody structure, woody canopy, woody structure below canopy, woody patchiness, woody diversity, herbaceous diversity, herbaceous patchiness, large herbivore diversity, ant diversity, dung beetle diversity, butterfly diversity, small mammal diversity, frog and reptile diversity, bird diversity and degradation, all weighted between
1 and 4 for a total maximum weighted score of 32 .

of each measure (Gerrodette 1987). Current research needs to facilitate appropriate monitoring should focus on defining designs that allow optimal precision with regard to methodology, survey trade-offs and analytical techniques. Such directives can then inform and focus monitoring to evaluate the SANParks objectives at various scales.

In this paper we therefore also highlight constraints of traditional approaches and explore particularly why many existing SANParks TPCs have not been addressed. We propose three key approaches and define likely measures of outcome success, which relate to a more process-based approach for defining TPCs. As a first step we revisit the applicability of TPCs and propose an alternative conceptual TPC. We then introduce an approach to deal with rare, cryptic and difficultly sampled taxa. We evaluate the value of species abundance and trends, but also highlight the constraints. In the final step, we introduce ecosystem outcome indicators. Based on these discussions we provide conceptual examples of park monitoring programmes directed at assessing the conservation outcomes of maintaining species and communities that are affected by large herbivores. Large herbivores are the focus for this conceptual discussion because they often form a key part of the conservation management decisions of SANParks.

\section{Thresholds of potential concern revisited}

The TPC approach adopted by SANParks (Biggs \& Rogers 2003) uses a range of possible ecosystem states as guidelines. This acknowledges that ecosystems are in flux and tend to vary across space and time (Biggs \& Rogers 2003). The challenge is to define acceptable variation.

SANParks can expect that ecosystems will be bounded and may actually have some form of equilibrium dynamics. This is because different areas provide different environmental limitations (Belsky 1990; John et al. 2007; Walker 1987), species have physiological limits (Weiner 1992) and they respond to other species (Agrawal 2001). Such limitations mean that a small, finite number of possible states exist (Stringham, Krueger \& Shave 2003). Conservationists may consider systems to reflect the 'balance' versus the 'flux' of nature (Pimm 1991), which depends on the temporal and spatial scale perceived, whether assumed or enforced (Figure 1). The reality is that conservationists, irrespective of the paradigm they adhere to, guide their management strategies such that a system can adopt any state as long as it does not lose a key property.

Given that diversity and ecosystem resilience are associated with heterogeneity (Christensen 1997), should SANParks 
manage for heterogeneity? If so, what would be an acceptable level of flux? The mechanisms underlying development and maintenance of heterogeneity give some direction (Figure 2). Agents that act on a specific feature to effect change are not the same as those factors that control and maintain the change once it has taken place. The balance paradigm changes controllers to agents and vice versa, which may force equilibrium values over scales that are inappropriate. The outcomes are likely to contrast conservation objectives. The realisation that the balance paradigm challenges achieving common biodiversity objectives means that SANParks needs measures and TPCs that reflect outcomes of heterogeneity.

The heterogeneity paradigm is sensibly adopted by SANParks (Du Toit et al. 2003). For systems that are relatively intact, setting TPCs is a rational way of defining outcomes which a monitoring programme should evaluate and inform (e.g. Foxcroft 2009). This is advanced by the fact that the number of states is limited and that the range depends on the biome and system responses to disturbances. For example, arid systems may change little in the face of disturbance (i.e. they are resistant) whereas more mesic systems may recover quickly in the face of disturbance (i.e. they are resilient), as described by Pimm (1991).

However, most of the areas that SANParks manages are conceivably degraded. Many have an agricultural history prior to proclamation, or have an intense management history that embraced balance-paradigm approaches. Within a heterogeneity paradigm the challenge is to define something as degraded as well as determining how such a system can be restored. In reality, SANParks cannot define the 'natural' state and is left with providing opportunities for ecological processes to play out through restoration or, if impossible, mimic outcomes. The traditional use of TPCs to define a range of states may carry little value in such cases. SANParks thus needs a conceptual approach to set TPCs for degraded areas, which can then direct monitoring programmes within the constraints highlighted earlier. Such TPCs may formally be defined as targets.

Degraded systems can be considered when a strong driver has changed the system to such an extent that the system has lost function, diversity or structure (Aradóttir \& Arnalds 2001; Hüttl \& Schneider 1998). Driver changes are often human induced (Aradóttir \& Arnalds 2001). Subsequent restoration involves human activities directed at instituting a set of processes to guide the system towards the range of acceptable ecosystem states (Society for Ecological Restoration 2004). It means that a TPC needs measures with direction and trends, not just a range of states. Such measures and TPCs will be constrained by the limitations of detecting trends, much as the detection of changes in species abundance is constrained by several trade-off factors (Gerrodette 1987). Although restoration constitutes the process of assisting recovery, success ultimately depends on whether populations, communities and ecological functions attain limits typical of nondegraded reference systems (Wassenaar et al. 2007). With evidence increasing that removing stressors is not always sufficient to guarantee restoration success, the true arbiters will be the organisms and processes at which restoration is aimed. Stringent appraisal of these ecological criteria will be required if restored systems are to conserve biodiversity and deliver ecosystem services (Ormerod 2003).

As argued thus, SANParks can develop a generalisation of TPC. States are limited because of restricted species pools, specific niche needs and constrained species coexistence due to species interactions (Wassenaar et al. 2005). However, the 'natural state' is unknown and is most likely dynamic (Pimm

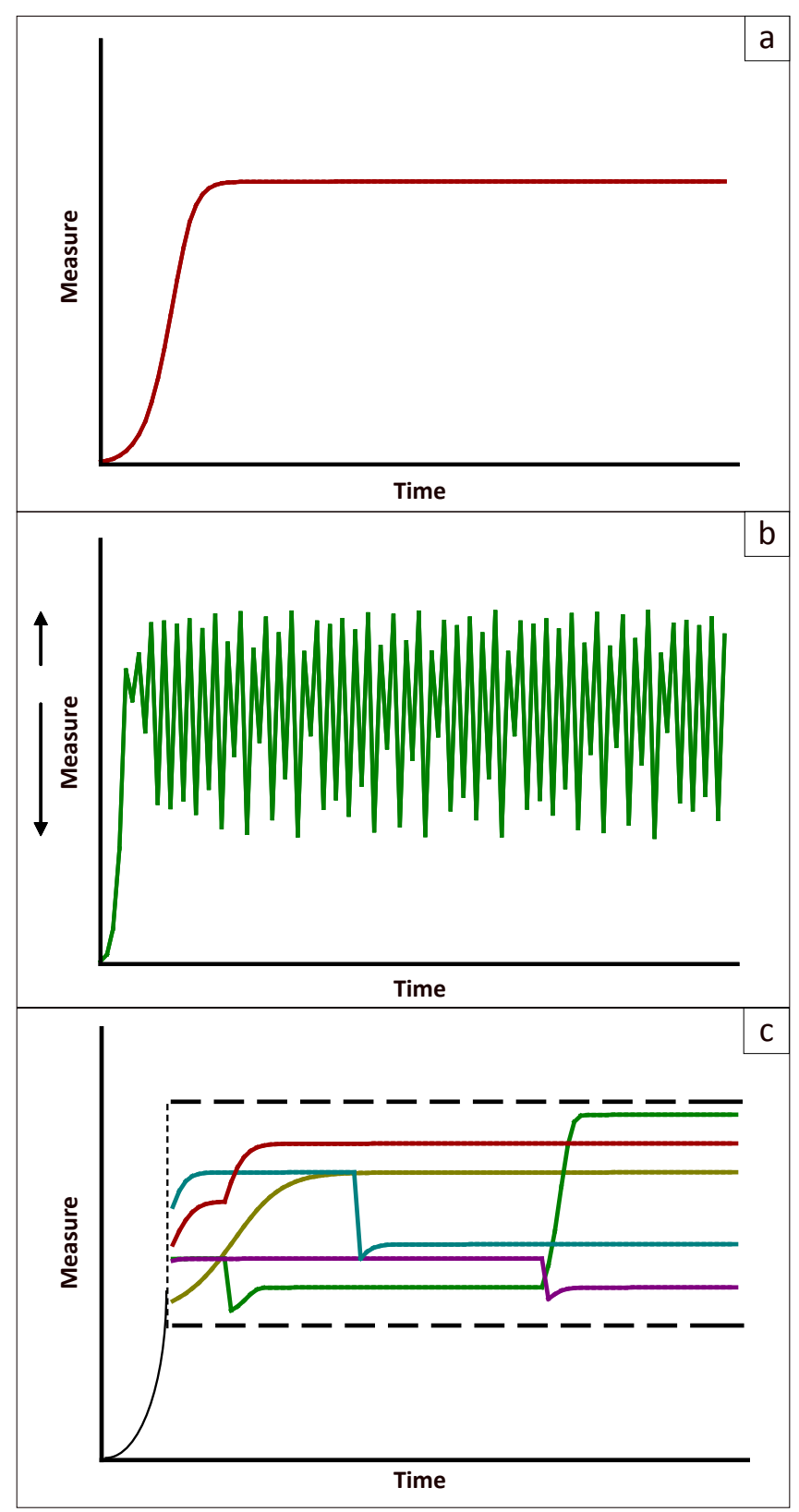

a, balance; b, flux; c, spatially explicit.

Many of the outcomes are dependent on the time scale of an observation. However, the spatial scale is most critical, because very strong local equilibrium dynamics may lead to flux and heterogeneity observed within an area, as reflected in dynamic patch hierarchies (Kotliar, N.B. \& Wiens, J.A., 1990, 'Multiple scales of patchiness and patch structure: a hierachical framework for the study of heterogeneity', Oikos 59, 253-260. doi:10.2307/3545542). Measure refers to any feature including population size or a community measure. Spatially explicit cases refer to various possible trajectories at different places leading to patch hierarchies as described by Kotliar and Wiens (1990).

FIGURE 1: Outcomes of the balance versus flux paradigms of ecosystem dynamics. 


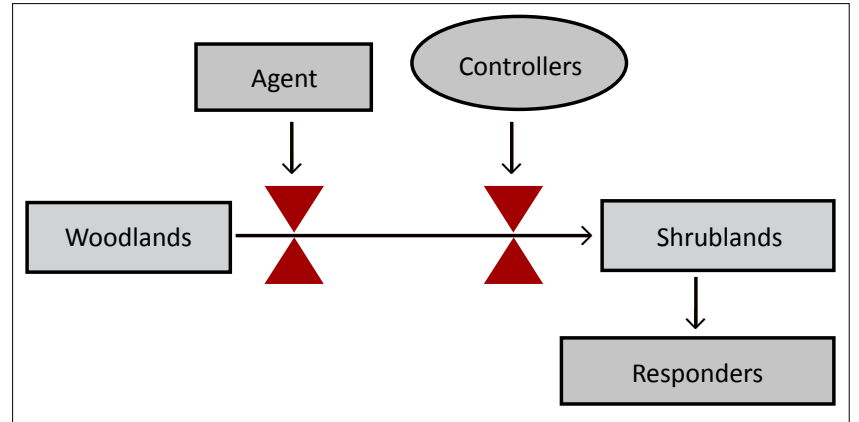

FIGURE 2: Interactions between agents (e.g. elephants) that act on a substrate (e.g. woodlands) to change it from one state to an alternative state (e.g. shrublands). However, the maintenance of the shrublands state is controlled by something else (e.g. kudu, impala and mice) other than the agent (adapted from Pickett, T.A., Cadenasso, M. \& Benning, T., 2003, 'Biotic and abiotic variability as key determinants of savannah heterogeneity at multiple spatiotemporal scales', in J.T. du Toit, K.H. Rogers \& H.C. Biggs (eds.), The Kruger Experience: Ecology and management of savanna heterogeneity, pp. 22-40, Island Press, Washington DC). Several other aspects of an ecosystem may respond (e.g. birds) to this sustained change.

1991). For this very reason, the management objective should be simple: to provide opportunities for spatial and temporal variability in processes that will lead to dynamic states. In this context state-transition models (e.g. Stringham et al. 2003) may hold great value in helping to prioritise which transitions are undesirable (usually human induced - see Chapin et al. (2000) and Daszak et al. (2000)) in the context of set objectives and allow conservationists to define TPCs to indicate such transitions or changes. Measuring state change can be applied to intact or recovering degraded systems. In both intact and degraded cases thresholds reflect spatial variability through a distribution of changes, and temporal variability through a distribution of variance in changes. For example, changes in vegetation may be considered nondetrimental if study sites within landscapes comprising specific areas have different rates of change, that is, spatial heterogeneity. For intact systems, conservationists should anticipate that this distribution of rates of change centres on zero, whilst for degraded systems the distribution should centre on a value not equal to zero (Biggs et al. 2011). Setting TPCs according to this approach requires substantial assessment of trends at all levels. The guideline above is thus relevant to support SANParks fully in evaluating outcomes of management actions directed at achieving various objectives.

\section{Linking thresholds of potential concerns}

Monitoring is directed at evaluating objectives at several scales, including at park and national level (Dickens \& Graham 2002; Noon et al. 1999; Noss 1990; Possingham et al. 2001). Defining the linkages between management actions and objectives is a key step in deciding on the appropriate action, anticipated consequences and subsequent measurement (Figure 3). In this paper we focus on direct measures of objectives. The unpacking of a concern, as described by Gaylard and Ferreira (2011), clearly illustrates how measuring SANParks objectives in a strategic adaptive management framework (Biggs \& Rogers 2003) forces conservationists to monitor from individual species to ecosystem level. This allows determining whether the proposed mechanism of a concern has been adequately addressed through a management action.

\section{Rare, endemic and cryptic species}

Most species are rare (Cao, Williams \& Williams et al. 1998; McArdle 1990), and rarity in itself poses significant problems for evaluating changes (Cao et al. 1998). Estimation of population sizes carries high uncertainty when populations are small (MacKenzie et al. 2005; Owen \& Rosentreter 1992). We propose that SANParks should focus on inventory techniques used in a predictive manner to evaluate its success with regard to achieving its biodiversity objectives. The process accommodates typical adaptive management approaches, with each cycle having a learning element. As shown in Table 3, the initiation has two phases:

- informed guessing based on expert knowledge because data are often too restrictive to construct formal landscape models

- predicting species presence based on landscape characteristics.

The proposed inventory monitoring requires some initial research. Firstly, the degree of survey effort required to identify what species are present at a site (e.g. Lewis \& Gould 2000; MacKenzie \& Royle 2005) needs to be established. This will most likely take the form of a species accumulation curve with effort (Colwell \& Coddington 1994), based on rarefaction methods (Gotelli \& Colwell 2001) and field data. Secondly, the required number of sites to develop predictive models regarding species absence or presence need to be determined.

\section{Selected species abundances, trends and impacts}

Several species require and lend themselves to assessments of population sizes and associated trends (Carter et al. 1995). This holds enormous value because population growth is a summary of a species' response to the environment, other species and its own members (Dann 1992; Sibly et al. 2005).

Assessment of population sizes needs to recognise that conservationists can seldom, if ever, provide accurate (bias ${ }^{2}$ + precision) estimates (Critchley \& Poulton 1998). However, in the past conservationists have seldom reported precision (standard deviation, confidence intervals, etc.) for estimates (e.g. Bauer \& Van der Merwe 2004; Blanc et al. 2007). This may have influenced interpretation of information dramatically, because any technique for estimating population sizes entails several sources of error that introduce uncertainty to the estimate. These sources of error include sampling bias when a sample-based approach is used (Walsh et al. 2001). However, even total counts commonly used by SANParks (e.g. Van Aarde, Whyte \& Pimm 1999) or registration studies (e.g. Gough \& Kerley 2006) may introduce biases relating to observers, availability and detectability (Caughley 1974; Redfern et al. 2002). We propose that these biases should be formally assessed, particularly with regard to the assessment of large mammal species. In addition to bias, sampling effort also affects precision of population estimates (Ferreira \& Van Aarde 2009). 


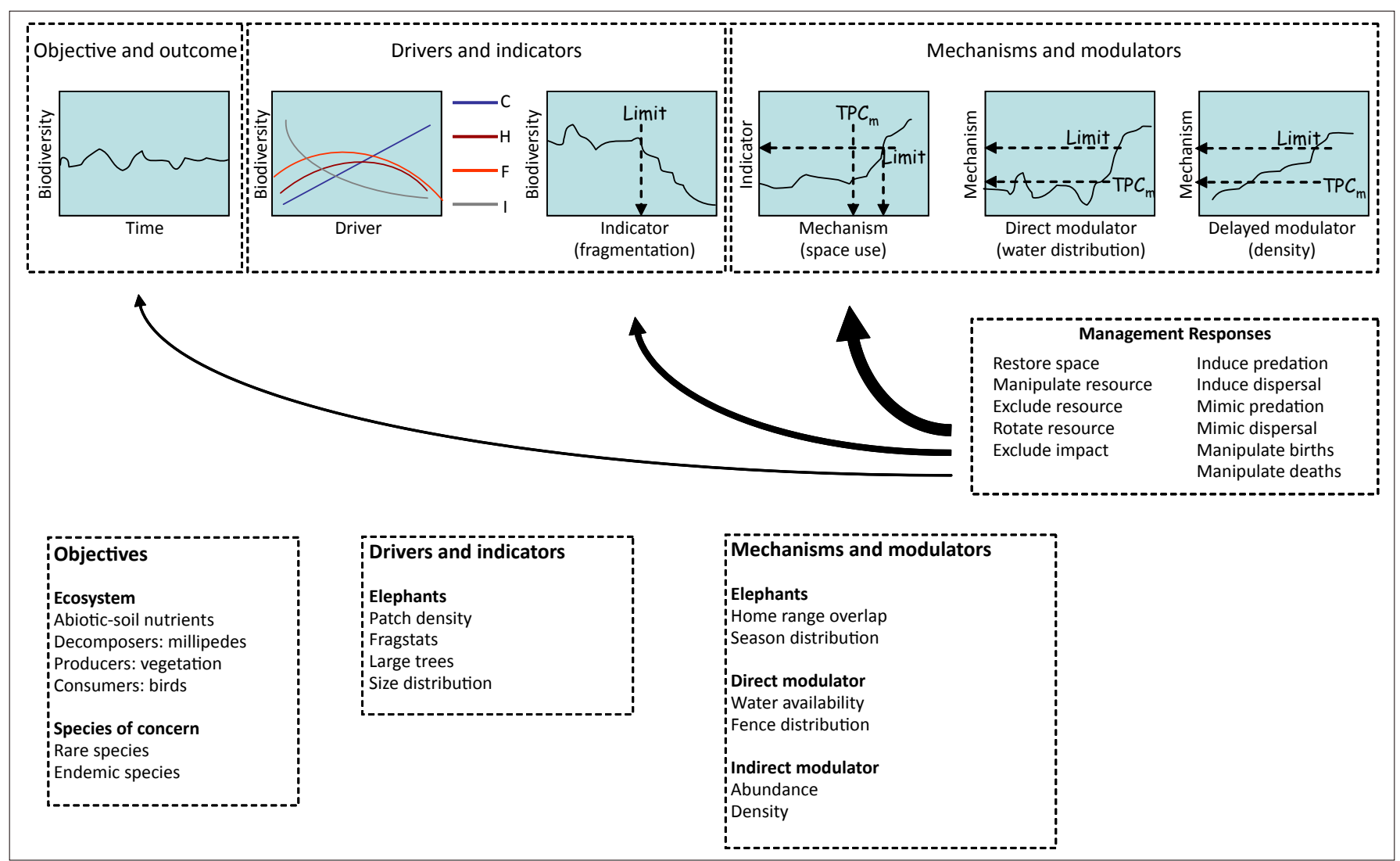

FIGURE 3: SANParks uses a linkage framework that connects objectives, drivers, mechanisms and modulators. Typically, conservationists seek nondirectional variance in biodiversity over time - a key objective. A hypothetical set of linkages relate ecosystem (biodiversity) objectives to key drivers and an indicator of such a driver. There are also linkages to the likely mechanism of how a driver affects biological diversity and factors that act as modulators on the mechanism. This example uses elephants and illustrates that management responses focus on modulators and that information requirements are diverse (Adapted from Gaylard, A. \& Ferreira, S.M., 2011, 'Modification and maturation of SANPark's adaptive planning process - making critical linkages between conservation objectives and actions', Koedoe 53(2), Art. \#1005, 8 pages. doi:10.4102/koedoe.v53i2.1005).

TABLE 3: Example of a predictive inventory approach for rare species and species of special concern inhabiting nondegraded areas.

\begin{tabular}{ll}
\hline Phase & Approach \\
\hline Phase 1 & - At the onset conservationists use informed guesses to predict the expected presence of species for each landscape given the topography and habitat available. \\
& - An inventory using optimal survey efforts follows. \\
& - Researchers compare observed with expected presence of species, having corrected the expected presence for the survey effort applied. \\
& - Landscape characters recorded at the time of the sampling as well as through remote sensing techniques are collated. \\
- Landscape selection models are developed for each species where data allow; else the approach reverts to Phase 1. & \\
& - Researchers predict expected species from landscape selection models. \\
& - An inventory using optimal survey efforts follows. \\
& - Researchers compare observed with expected presence of species, having corrected the expected presence for the survey effort applied.
\end{tabular}

The precision of population estimates has a critical value because the detection of trends in a time series of population estimates depends on several factors (Figure 4), one of which is the precisions of population estimates. Estimates of precision help to minimise Type I and Type II errors (concluding there is a trend when, in fact, there is none and concluding there is no trend when, in fact, there is, respectively), which may have dire consequences for conservation decisions if undetected (Critchley \& Poulton 1998). Monitoring designs have to consider trade-offs imposed by precision: for a desired level of precision, conservationists may be better off counting less often, with longer intervals between counts, but achieving better trend detection.

In addition, monitoring selected species for trends regarding abundance usually is most valuable when linked explicitly to the impact on objectives. Large mammals are of particular importance in this context (e.g. Gordon, Hester \& FestaBianchet 2004). However, impacts by large mammals on other values are primarily associated with the degree to which mammals are using specific places (e.g. Van Aarde et al. 2006; Van Aarde \& Jackson 2007). Intensity of use is primarily driven directly by the distribution of critical resources (e.g. Harris et al. 2008; Loarie, Van Aarde \& Pimm 2009) and indirectly by abundance (e.g. Young, Ferreira \& Van Aarde 2009). Detecting change with regard to impact and intensity of use carries the same trade-off as detecting trends in population estimates. These aspects need further development for defining monitoring of objectives associated with large mammals.

Given that intensity of use is the likely mechanism through which large mammals will affect ecosystems (Table 4), 
information needs may substantially exceed what SANParks generates at present. Using the 'Objective, indicators, mechanisms and modulators' approach suggests that information relating to large mammals needs to include regional distribution, intensity of use and demography (Table 5).

\section{Ecosystem indicators: Ecological, community-based assessments}

Community structure is the outcome of interactions between ecological processes (Bradshaw 2000; Prach et al. 2001). The evaluation of ecosystem management approaches (i.e. those actions that provide the opportunity for ecological processes to play out) may best be achieved by measuring temporal and spatial variation in key communities (i.e. those that are important for specific objectives of a national park). This could help SANParks to assess its ecosystem objectives and adhere to the complexity value that SANParks embraces (Biggs \& Rogers 2003). Evaluation of multivariate data sets that reflect various ecosystem processes may be a conceptual approach towards reflecting on ecosystem outcomes. Such multivariate data sets can include abiotic, producer, decomposer and consumer aspects (e.g. Van Aarde et al. 1996). SANParks can gather several kinds of information to compile such data sets, including species composition, soil structures, vegetation cover assessments, landscape features and water quality assessments.
We propose using multivariate data as the basis of ecosystem feature evaluation. Sampling effort therefore needs to maximise the detection of species and species accumulation curves could potentially be used as an indicator (Colwell \& Coddington 1994). SANParks should also be able to define differences and/or changes in multivariate indicators. Biological communities for which data comprise species composition and a measure of abundance are used most often.

Differences and/or changes in multivariate data in the context of evaluating ecosystem objectives can be measured using either simple or complex parameters (Figure 5). Such measures are useful for two reasons. Firstly, they allow SANParks to assess directional change in systems (e.g. Wassenaar et al. 2005; Wassenaar et al. 2007) and therefore can be used to direct maintenance as well as restoration conservation. Secondly, these measures allow SANParks to relate biological community changes to other factors such as intensity of fires or the local density of large mammals, thereby supporting assessment of the links between management actions and objectives (see Figure 3).

\section{The generality of monitoring across parks}

The conceptual approach described here may present several challenges. Some parks, for instance, may need case-by-

Type I error - concluding there is a trend when there is none $-\alpha=0.05$
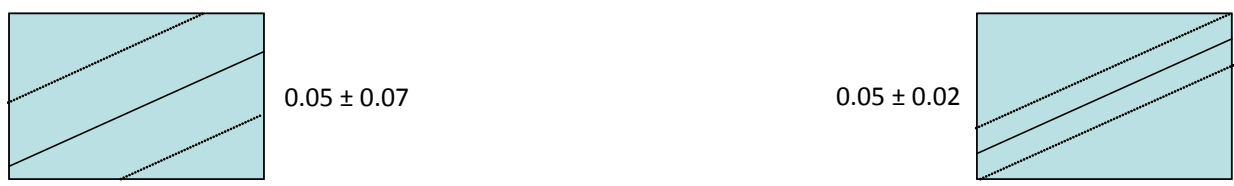

Type II error - concluding there is no trend when there is one $\mathbf{- \beta}=\mathbf{0 . 2}$

Detecting a trend $(1-\beta=0.8)$ depends on growth rate, variance, intervals and number of surveys
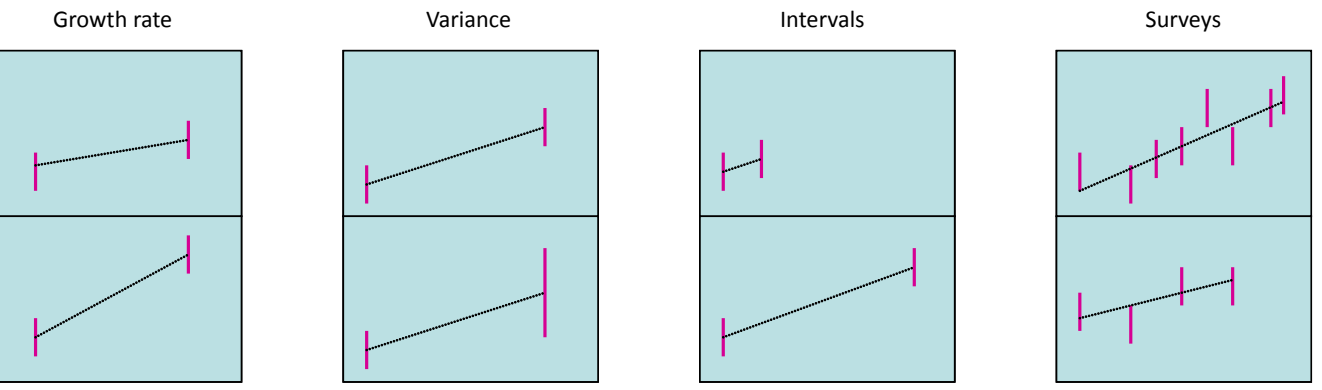

$$
[\ln (1+r)]^{2} n(n-1)(n+1) \geq 12\left(z_{\alpha / 2}+z_{\beta}\right)^{2}\left\{\frac{1}{n} \sum_{i=1}^{n} \ln \left[\frac{c v_{1}^{2}}{(1+r)^{i-1}}+1\right]\right\} \quad \text { Gerrodette } 1987
$$

FIGURE 4: Detecting population trends are constrained by Type I and Type II errors. Researchers traditionally accommodate Type I errors and usually conclude that there is no trend when $\alpha>0.05$. However, Type II errors may have as important consequences. For example, a researcher may conclude that there is no declining trend when $\alpha>0.05$ for a threatened species, when, in fact, there was a high probability for a Type II error, which may ultimately lead to local extinction. The power to detect a trend carries several trade-offs illustrated in the diagram. This includes the magnitude of the trend to be detected, the variance of population estimates, the intervals between surveys and the number of surveys (Gerrodette, T., 1987, 'A power analysis for detecting trends', Ecology 68, 1364-1372. doi:10.2307/1939220). 
TABLE 4: Herbivory concerns unpacked across selected parks managed by SANParks, to illustrate how monitoring needs driven by linkages to objectives, mechanisms and modulators require a spectrum of monitoring information, but also many commonalities (SANParks unpublished records).

\begin{tabular}{|c|c|c|c|c|c|}
\hline Park & Concern & Measure & Driver & Mechanism & Measuring the mechanism \\
\hline Marakele & Loss of plant species & $\begin{array}{l}\text { Expected versus predicted } \\
\text { distribution of plant species }\end{array}$ & Elephant & $\begin{array}{l}\text { - Space use homogenised by water } \\
\text { distribution } \\
\text { - Space use homogenised by density } \\
\text { - Selective feeding intensified by } \\
\text { density }\end{array}$ & $\begin{array}{l}\text { - Space use by elephants as water } \\
\text { distribution change } \\
\text { - Space use by elephants as densities } \\
\text { change }\end{array}$ \\
\hline \multirow[t]{3}{*}{ Augrabies } & $\begin{array}{l}\text { Grazing impacts by } \\
\text { domestic livestock }\end{array}$ & $\begin{array}{l}\text { Biological community } \\
\text { changes }\end{array}$ & Livestock & $\begin{array}{l}\text { - Space use homogenised by herding } \\
\text { - Intensity of grazing homogenised } \\
\text { - Feeding intensified by density }\end{array}$ & $\begin{array}{l}\text { - Space use of livestock associated } \\
\text { with water distribution and herding } \\
\text { - Size of livestock herds }\end{array}$ \\
\hline & & & Baboon & $\begin{array}{l}\text { - Feeding on flowers } \\
\text { - Reduced reproductive output } \\
\text { - Break branches } \\
\text { - Potential infections lead to tree } \\
\text { death } \\
\text { - High death rates and low } \\
\text { reproduction lead to decline in the } \\
\text { population }\end{array}$ & $\begin{array}{l}\text { - Intensity of use by baboons } \\
\text { - Spatial use of baboons } \\
\text { - Density of baboons }\end{array}$ \\
\hline & & & Porcupine & $\begin{array}{l}\text { - Debarking of stems } \\
\text { - Lead to tree death } \\
\text { - High death rates lead to decline in } \\
\text { populations }\end{array}$ & $\begin{array}{l}\text { - Intensity of use by porcupines } \\
\text { - Distribution of porcupines }\end{array}$ \\
\hline \multirow[t]{2}{*}{ Mokala } & Declining camel thorn trees & $\begin{array}{l}\text { s Age structure of camel } \\
\text { thorn trees }\end{array}$ & Porcupine & $\begin{array}{l}\text { - Debarking of stems } \\
\text { - Lead to tree death } \\
\text { - High death rates lead to decline in } \\
\text { populations }\end{array}$ & $\begin{array}{l}\text { - Intensity of use by porcupines } \\
\text { - Distribution of porcupines }\end{array}$ \\
\hline & $\begin{array}{l}\text { Grazing impacts on } \\
\text { biodiversity }\end{array}$ & $\begin{array}{l}\text { Biological community } \\
\text { changes }\end{array}$ & $\begin{array}{l}\text { Mainly buffalo, but also } \\
\text { several other species }\end{array}$ & $\begin{array}{l}\text { - Space use homogenised by water } \\
\text { distribution } \\
\text { - Space use homogenised by density } \\
\text { - Selective feeding intensified by } \\
\text { density }\end{array}$ & $\begin{array}{l}\text { - Space use by species as water } \\
\text { distribution changes } \\
\text { - Space use by species as densities } \\
\text { change }\end{array}$ \\
\hline \multirow[t]{2}{*}{ Addo } & $\begin{array}{l}\text { Loss of particular plant } \\
\text { species }\end{array}$ & $\begin{array}{l}\text { Expected versus predicted } \\
\text { distribution of plant species }\end{array}$ & Elephant, black rhino & $\begin{array}{l}\text { - Density of elephants homogenise } \\
\text { space use } \\
\text { - Selective feeding altered by } \\
\text { megaherbivores } \\
\text { - Certain species are no longer there } \\
\text { or in really low numbers } \\
\text { - This result from reduced browse } \\
\text { quality } \\
\text { - Intensified foraging of selected } \\
\text { plants } \\
\text { - Leads to declines }\end{array}$ & $\begin{array}{l}\text { - Space use by elephants as water } \\
\text { distribution changes } \\
\text { - Space use by elephants as densities } \\
\text { change } \\
\text { - Space use by black rhino }\end{array}$ \\
\hline & $\begin{array}{l}\text { Change in vegetation } \\
\text { structure }\end{array}$ & $\begin{array}{l}\text { Vegetation community } \\
\text { changes }\end{array}$ & $\begin{array}{l}\text { Elephant, } \\
\text { other herbivores }\end{array}$ & $\begin{array}{l}\text { - Homogenised feeding owing to } \\
\text { density of elephants } \\
\text { - Food available to other browsers } \\
\text { changed }\end{array}$ & $\begin{array}{l}\text { - Space use by elephants as water } \\
\text { distribution changes } \\
\text { - Space use by elephants as densities } \\
\text { change } \\
\text { - Space use by other browsers }\end{array}$ \\
\hline
\end{tabular}

case management decisions, which could impact differently across several management tiers in SANParks. Even so, these may share mechanisms characteristic of a specific type of concern. To illustrate this, we collated all the herbivory concerns that have been expressed at various sciencemanagement interactions across several parks (Table 4). For each case we unpacked the detail underlying the concern. For example, degrading vegetation results from elephants spending too much time in a specific area, which, in turn, is governed by critical resources such as water (Van Aarde et al. 2006). Conservationists therefore need to understand the temporal and spatial distribution of water sources, the relationship between elephant spatial use and water, and vegetation changes related to elephant spatial use. Although the concerns are varied, monitoring needs converge onto commonalities. The commonalities illustrate information needs of which the emphasis has shifted from a number focus to a systems and biodiversity approach.
SANParks needs to find measures that evaluate whether the focus of a concern has changed. This may be well served through (1) a predictive inventory approach with residuals

TABLE 5: Example of information needs of SANParks based on the requirements of monitoring to support and evaluate management actions and their effects on objectives and summary of current data sets available for the specific example.

\begin{tabular}{|c|c|}
\hline Information needs & Available information \\
\hline $\begin{array}{l}\text { Regional distribution } \\
\text { - historic } \\
\text { - climate }\end{array}$ & - \\
\hline $\begin{array}{l}\text { Intensity of use } \\
\text { - local distributions } \\
\text { - individual spatial use } \\
\text { - modelled species spatial use } \\
\text { - relation to biodiversity }\end{array}$ & $\begin{array}{l}\text { Intensity of use } \\
\text { - local distributions } \\
\text { - relation to biodiversity }\end{array}$ \\
\hline $\begin{array}{l}\text { Demography } \\
\text { - births } \\
\text { - deaths }\end{array}$ & - \\
\hline $\begin{array}{l}\text { Abundances } \\
\text { - densities } \\
\text { - population growth rates }\end{array}$ & $\begin{array}{l}\text { Abundances } \\
\text { - densities or population sizes } \\
\text { - population growth rates }\end{array}$ \\
\hline
\end{tabular}




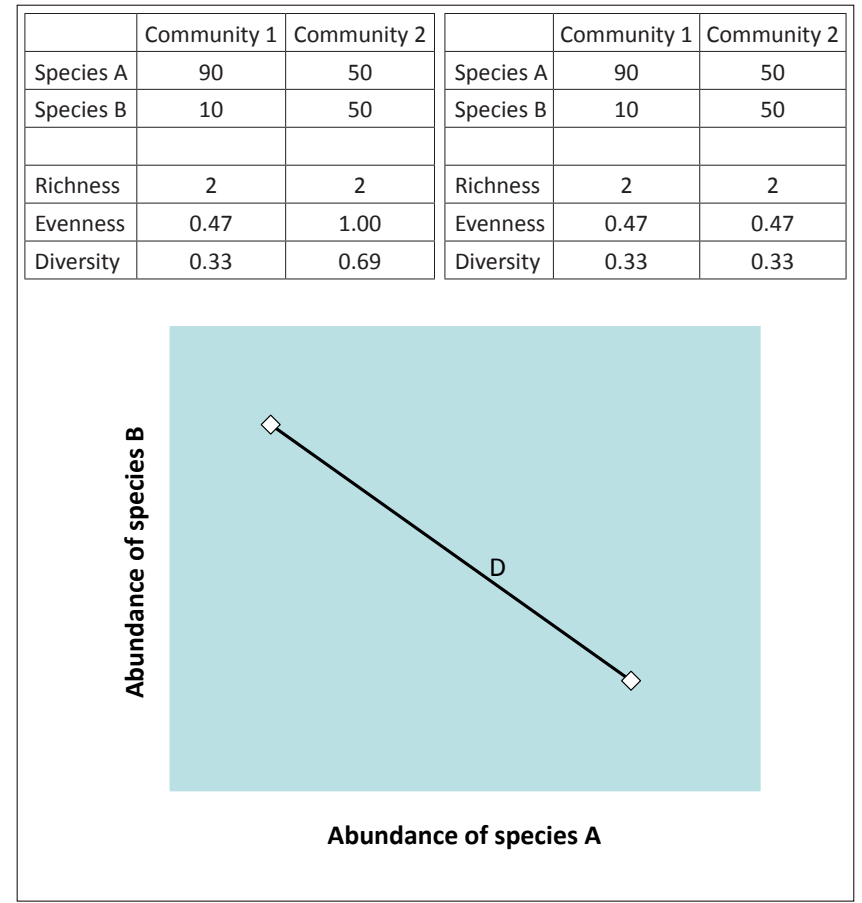

FIGURE 5: Illustration of two scenarios of communities that differ and how simple measures can distinguish communities in some instances, but not so in other instances. To overcome this, we propose the use of dissimilarity measures such as an Euclidean distance $(D)$ illustrated here.

of observed versus expected species presence at sample sites as indicators of ecosystem health and (2) a multivariate approach to evaluate the response of biological communities to management-induced changes in herbivory.

Evaluating the ecological mechanisms leading to a herbivory concern converge onto defining spatial use and the effects of its direct modulators as well as those of indirect modulation resulting from abundance or density. These commonalities illustrate that the approach to use large mammal censuses as a primary basis of decision making in SANParks (e.g. Kruger et al. 2008) requires additional information to assess fully whether management objectives have been reached within an adaptive management framework (Biggs \& Rogers 2003). However, such approaches may be comparable across parks.

The unpacking of a specific concern into mechanisms clearly illustrates a need to analyse how changes in the concern need to be associated with spatial use of large herbivores. This, in turn, needs to be associated with factors affecting spatial use to relate how management actions affect a concern.

Although the conceptual discussion used herbivory as a key example, the unpacking of concerns into mechanisms can easily be applied to all SANParks objectives (see Gaylard \& Ferreira 2011). It is likely that other common concerns will have similar commonalities with regard to drivers, mechanisms and modulators across parks. In addition, unpacking concerns defines measurement parameters and inadvertently prioritises monitoring tasks. This approach forms the focus of one of the programmes of the Biodiversity Monitoring Strategy of SANParks (McGeogh et al. 2011).

\section{Conclusions}

SANParks adopted a strategic adaptive management approach for managing complex systems in the face of uncertainty by implementing TPCs. However, the success of defining and implementing TPCs across several parks has been variable, partly because of unfamiliar definitions, case-specific constraints on the applicability of statebased TPCs, logistical and methodological challenges with regard to measurement and, finally, challenges relating to prioritising the magnitude of TPC-generated tasks. Given the dynamic nature of system processes, TPCs that define directional changes and associate with mechanisms may best serve the adaptive management approach that SANParks has embraced. Such approaches share common features when concerns that may impose on the SANParks mandate are unpacked into drivers, mechanisms and associated modulators. In addition, they define the shift in information needs from numbers to ecosystems and biodiversity, and prioritise monitoring programmes that feed directly into key management issues, appropriate responses and consequences of the chosen management actions.

\section{References}

Ackoff, R.L., 2010, Systems thinking for curious managers, Triarchy Press, Devon.

Agardi, T., 2000, 'Information needs for marine protected areas: scientific and societal', Bulletin of Marine Science 66, 875-888.

Agrawal, A.A., 2001, 'Phenotypic plasticity in the interactions and evolution of species', Science 294, 321-326. doi:10.1126/science.1060701, PMid:11598291

Aradóttir, Á.L. \& Arnalds, O., 2001, 'Ecosystem degradation and restoration of birch woodlands in Iceland', in F.E. Wielgolaski (ed.), Nordic Mountain Birch Ecosystems, pp. 293-306, Parthenon, Paris.

Bauer, H. \& Van der Merwe, S., 2004, 'Inventory of free-ranging lions Panthera leo in Africa', Oryx 38, 26-31. doi:10.1017/\$0030605304000055

Belsky, A.J., 1990, 'Tree/grass ratios in East African savannas: a comparison of existing models', Journal of Biogeography 17, 483-489. doi:10.2307/2845380

Biggs, H.C. \& Rogers, K.H., 2003, 'An adaptive system to link science, monitoring, and management in practice', in J.T. du Toit, K.H. Rogers \& H.C. Biggs (eds.), The Kruger Experience: Ecology and management of savanna heterogeneity, pp. 59-80, Island Press, Washington DC.

Biggs, H.C., Ferreira, S.M., Freitag-Ronaldson, S. \& Grant-Biggs, R., 2011, 'Taking stock after a decade: does the "thresholds of potential concern" concept need a socio-ecological revamp?', Koedoe 53(2), Art. \#1002, 9 pages. doi:10.4102/ koedoe.v53i2.1002.

Blanc, J.J., Barnes, R.F.W., Craig, G.C., Dublin, H.T., Thouless, C.R., Douglas-Hamilton, I., et al., 2007, African Elephant Status Report 2007: An Update from the African Elephant Database, IUCN/SSC African Elephant Specialist Group, Gland. doi:10.2305/IUCN.CH.2007.SSC-OP.33.en

Bocking, S., 1994, 'Visions of nature and society: A history of the ecosystem concept', Alternatives 20, 12-19.

Braaz, S., 1992, Conserving biological diversity: a strategy for protected areas in the Asia-Pacific region, World Bank, Washington DC.

Bradshaw, A.D., 2000, 'The use of natural processes in reclamation - advantages and difficulties', Landscape and Urban Planning 51, 89-100. doi:10.1016/S01692046(00)00099-2

Brandon, K., Gorenflo, L.J., Rodrigues, A.S.L. \& Waller, R.W., 2005, 'Reconciling biodiversity conservation, people, protected areas, and agricultural suitability in Mexico', World Development 33, 1403-1418. doi:10.1016/j.worlddev.2004.10.005

Brandon, K., Redford, K.H. \& Sanderson, S.E., 1998, Parks in peril: people, politics, and protected areas, Island Press, Washington DC.

Bruner, A.G., Gullison, R.E., Rice, R.E. \& Da Fonseca, G.A.B., 2001, 'Effectiveness of parks in protecting tropical biodiversity', Science 291, 125-128. doi:10.1126/ science.291.5501.125, PMid:11141563

Brussard, P.F., Reed, J.M. \& Tracy, C.R., 1998, 'Ecosystem management: what is it really?', Landscape and Urban Planning 40, 9-20. doi:10.1016/S01692046(97)00094-7

Cao, Y., Williams, D.D. \& Williams, N.E., 1998, 'How important are rare species in aquatic community ecology and bioassessment?', Limnology and Oceanography 43, 1403-1409. doi:10.4319/lo.1998.43.7.1403

Carter, H.R., Sowls, A.L., Rodway, M.S., Wilson, U.W., Lowe, R.W., McChesney., et al., 1995, 'Population size, trends, and conservation problems of the double-crested cormorant on the Pacific Coast of North America', in D.N. Nettleship \& D.C. Duffy (eds.), The double-crested cormorant: biology, conservation and management, pp. 189-215 (Colonial Waterbirds; vol. 18). 
Caughley, G., 1974, 'Bias in aerial survey', Journal of Wildlife Management 38, 921933. doi:10.2307/3800067 Chapin, F.S., Zavaleta, E.S., Eviner, V.T., Naylor, R.L., Vitousek, P.M., Reynolds, H.L.,
et al., 2000, 'Consequences of changing biodiversity', Nature 405, 234-242. doi:10.1038/35012241, PMid:10821284

Christensen, N.L., 1997, 'Managing for heterogeneity and complexity on dynamic landscapes', in S.T.A. Pickett, R.S. Ostfeld, M. Shachak \& G.E. Likens (eds.), The ecological basis of conservation: Heterogeneity, ecosystems and biodiversity, pp. 60-80, Chapman \& Hall, New York.

Colwell, R.K. \& Coddington, J.A., 1994, 'Estimating terrestrial biodiversity through extrapolation', Philosophical Transactions of the Royal Society of London B 345, 101-118. doi:10.1098/rstb.1994.0091, PMid:7972351

Critchley, C.N.R. \& Poulton, S.M.C., 1998, 'A method to optimize precision and scale in grassland monitoring', Journal of Vegetation Science 9, 837-846. scale in grassland moni
doi:10.2307/3237049

Curran, L.M., Trigg, S.N., McDonald, A.K., Astiani, D., Hardiono, Y.M., Siregar, P., et al., 2004, 'Lowland forest loss in protected areas of Indonesian Borneo', Science 303, 1000-1003. doi:10.1126/science.1091714, PMid:14963327

Dann, P., 1992, 'Distribution, population trends and factors influencing the population size of Little Penguins Eudyptula minor on Phillip Island, Victoria', Emu Australian Ornithology 91, 263-272. doi:10.1071/MU9910263

Daszak, P., Cunningham, A.A. \& Hyatt, A.D., 2000, 'Emerging infectious diseases of wildlife - threats to biodiversity and human health', Science 287, 443-449. doi:10.1126/science.287.5452.443, PMid:10642539

De Leo, G.A. \& Levin, S., 1997, 'The multifaceted aspects of ecosystem integrity', Conservation Ecology, vol. 1, viewed 02 February 2010, from http://www. consecol.org/vol1/iss1/art3

Dickens, C.W.S. \& Graham, P.M., 2002, 'The South African Scouring System (SASS) Version 5 rapid assessment method for rivers', African Journal of Aquatic Science 27, 1-10. doi:10.2989/16085914.2002.9626569

Doyle, T. \& McEachern, D., 2008, Environment and Politics, Routledge, New York.

Du Toit, J.T., Rogers, K.H. \& Biggs, H.C., 2003, The Kruger Experience: Ecology and management of savanna heterogeneity, Island Press, Washington DC.

Ferreira, S.M. \& Van Aarde, R.J., 2009, 'Aerial survey intensity as a determinant of estimates of African elephant population sizes and trends', South African Journal estimates of African elephant population sizes and trends', Sout
of Wildlife Research 39, 181-191. doi:10.3957/056.039.0205

Foxcroft, L.C., 2009, 'Developing thresholds of potential concern for invasive alien species: hypotheses and concepts', Koedoe 51, 1-6. doi:10.4102/koedoe. v51i1.157

Gaston, K.J., 2008, 'Biodiversity and extinction: the importance of being common', Progress in Physical Geography 32, 73-79. doi:10.1177/0309133308089499

Gaylard, A. \& Ferreira, S.M., 2011, 'Modification and maturation of SANPark's adaptive planning process - making critical linkages between conservation
objectives and actions', Koedoe 53(2), Art. \#1005, 8 pages. doi:10.4102/koedoe. v53i2.1005.

Gerrodette, T., 1987, 'A power analysis for detecting trends', Ecology 68, 1364-1372. doi:10.2307/1939220

Ghimire, K.B. \& Pimbert, M.P., 1997, Social change and conservation, Earthscan Publications, London.

Gordon, I.J., Hester, A.J. \& Festa-Bianchet, M., 2004, 'The management of wild large herbivores to meet economic, conservation and environmental objectives',
Journal of Applied Ecology 41,1021-1031. doi:10.1111/j.0021-8901.2004.00985.x

Gotelli, N.J. \& Colwell, R.K., 2001, 'Quantifying biodiversity: procedures and pitfalls in the measurement and comparison of species richness', Ecological Letters 4 , 379-391. doi:10.1046/j.1461-0248.2001.00230.x

Gough, K. \& Kerley, G.I.H., 2006, 'Demography and population dynamics in the elephants Loxodonta africana of Addo Elephant National Park, South Africa: is there evidence of density dependent regulation?', Oryx 40, 434-441. doi:10.1017/ S0030605306001189

Harris, G.M., Russell, G.J., Van Aarde, R.J. \& Pimm, S.L., 2008, 'Habitat use of savanna elephants in southern Africa', Oryx 42, 66-75. doi:10.1017/S0030605308000483

Hüttl, R.F. \& Schneider, B.U., 1998, 'Forest ecosystem degradation and rehabilitation', Ecological Engineering 10, 19-31. doi:10.1016/S0925-8574(97)10023-4

John, R., Dalling, J.W., Harms, K.E., Yavitt, J.B., Stallard, R.F., Mirabello, M., et al., 2007, 'Soil nutrients influence spatial distributions of tropical tree species', Proceedings of the National Academy of Sciences of the United States of Ameria 104, 864-869. doi:10.1073/pnas.0604666104, PMid:17215353, PMCid:1783405

Kay, J.J. \& Schneider, E., 1994, 'Embracing complexity: the challenge of the ecosystem approach', Alternatives 20, 32-46.

Knight, A.T., Driver, A., Cowling, R.M., Maze, K., Desmet, P.G., Lombard, A.T., et al., 2006, 'Designing systematic conservation assessments that promote effective implementation: best practice from South Africa', Conservation Biology 2, 203implemen.

Knight, M.H., 2007, SANParks State of Biodiversity Report (SOB) Background Sheet, SANParks, Pretoria.

Kotliar, N.B. \& Wiens, J.A., 1990, 'Multiple scales of patchiness and patch structure: a hierachical framework for the study of heterogeneity', Oikos 59, 253-260. doi: $10.2307 / 3545542$

Kruger, J.M., Reilly, B.K. \& Whyte, I.J., 2008, 'Application of distance sampling to estimate population densities of large herbivores in Kruger National Park', Wildlife Research 35, 371-376. doi:10.1071/WR07084

Lawton, J.H., 1997, 'The science and non-science of conservation', Oikos 79, 3-5. doi: $10.2307 / 3546084$
Lewis, C., 1996, Managing conflicts in protected areas, IUCN, Gland.

Lewis, S.A. \& Gould, W.R., 2000, 'Survey effort effects on power to detect trends in raptor migration counts', Wildlife Society Bulletin 28, 317-329.

Lindenmayer, D.B., Franklin, J.F. \& Fischer, J., 2006, 'General management principles and a checklist of strategies to guide forest biodiversity conservation', Biological Conservation 131, 433-445. doi:10.1016/j.biocon.2006.02.019

Lindenmayer, D.B. \& Likens, G.E., 2009, 'Adaptive monitoring: a new paradigm for long-term research and monitoring', Trends in Ecology and Evolution 24, 482-486. doi:10.1016/j.tree.2009.03.005

Liu, J., Linderman, M., Ouyang, Z., An, L., Yang, J. \& Zhang, H., 2001, 'Ecological degradation in protected areas: The case of Wolong Nature Reserve for giant pandas', Science 292, 98-101. doi:10.1126/science.1058104, PMid:11292872

Loarie, S.R., Van Aarde, R.J. \& Pimm, S.L., 2009, 'Fences and artificial water affect African savannah elephant movement patterns', Biological Conservation 142, 2086-3098. doi:10.1016/j.biocon.2009.08.008

Lyons, K.G., Brigham, C.A., Traut, B.H. \& Schwartz, M.W., 2005, 'Rare species and ecosystem functioning', Conservation Biology 19, 1019-1024. doi:10.1111/ j.1523-1739.2005.00106.x

MacKenzie, D.I., Nichols, J.D., Sutton, N., Kawanishi, K. \& Bailey, L.L., 2005, 'Improving inferences in population studies of rare species that are detected imperfectly', Ecology 86, 1101-1113. doi:10.1890/04-1060

MacKenzie, D.I. \& Royle, J.A., 2005, 'Designing occupancy studies: general advice and allocating survey effort', Journal of Applied Ecology 42, 1105-1114. doi:10.1111/ j.1365-2664.2005.01098.x

Margules, C.R. \& Pressey, R.L., 2000, 'Systematic conservation planning', Nature 405, 243-253. doi:10.1038/35012251, PMid:10821285

Martello, M.L., 2001, 'A paradox of virtue?: "other" knowledges and environmentdevelopment politics', Global Environmental Politics 1, 114-141. doi:10.1162/152638001316881430

McArdle, B.H., 1990, 'When are rare species not there?', Oikos 57, 276-277. doi:10.2307/3565950

McGeogh, M.A., Dopolo, M., Novellie, P., Hendricks, H., Freitag, S., Ferreira, S.M., et al., 2011, 'A strategic framework for biodiversity monitoring in SANParks', Koedoe 53(2), Art. \#991, 10 pages. doi:10.4102/koedoe.v53i2.991.

McNeely, J.A., 1994, 'Protected areas for the 21st century: working to provide benefits to society', Biodiversity and Conservation 3, 390-405. doi:10.1007/BF00057797

Milton, S.J., Dean, W.R.J., Du Plessis, M.A. \& Siegfried, W.R., 1994, 'A conceptual model of arid rangeland degradation', BioScience 44, 70-76. doi:10.2307/1312204

Morellet, N., Gaillard, J-M., Hewison, A.J.M., Ballon, P., Boscardin, Y., Duncan, P., et al., 2007, 'Indicators of ecological change: new tools for managing populations a., 'large herbivores', Journal of Applied Ecology 44, 634-643. doi:10.1111/j.1365-
of of large herbivores',
2664.2007.01307.x

Noon, B.R., Spies, T.A. \& Raphael, M.G., 1999, 'Conceptual basis for designing an effectiveness monitoring program', in B.S. Mulder (ed.), The strategy and design of the effectiveness of a monitoring program for the Northwest forest plan, $\mathrm{pp}$. 21-48, US Department of Agricultural Forest Service, Portland.

Noss, R.F., 1990, 'Indicators for monitoring biodiversity: a hierarchical approach', Conservation Biology 4, 355-364. doi:10.1111/j.1523-1739.1990.tb00309.x

Noss, R.F., 1999, 'Assessing and monitoring forest biodiversity: a suggested framework and indicators', Forest Ecology and Management 115, 135-146. doi:10.1016/ S0378-1127(98)00394-6

Ormerod, S.J., 2003, 'Restoration in applied ecology: editor's introduction', Journal of Applied Ecology 40, 44-50. doi:10.1046/j.1365-2664.2003.00799.x

Owen, W.R. \& Rosentreter, R., 1992, 'Monitoring rare perennial plants: techniques for demographic studies', Natural Areas Journal 12, 32-38.

Parrish, J.D., Braun, D.P. \& Unnasch, R.S., 2003, 'Are we conserving what we say we are? Measuring ecological integrity within protected areas', BioScience 53, 851860. doi:10.1641/0006-3568(2003)053[0851:AWCWWS]2.0.CO;2

Pickett, T.A., Cadenasso, M. \& Benning, T., 2003, 'Biotic and abiotic variability as key determinants of savannah heterogeneity at multiple spatiotemporal scales', in
J.T. du Toit, K.H. Rogers \& H.C. Biggs (eds.), The Kruger Experience: Ecology and J.T. du Toit, K.H. Rogers \& H.C. Biggs (eds.), The Kruger Experience: Ecology and
management of savanna heterogeneity, pp. 22-40, Island Press, Washington DC.

Pimm, S.L., 1991, The balance of nature? Ecological issues in the conservation of species and communities, University of Chicago Press, Chicago.

Possingham, H.P., Andelman, S.J., Noon, B.R., Trombulak, S. \& Pulliam, H.R., 2001, 'Making smart conservation decisions', in M.E. Soule \& G.H. Orians (eds.), Conservation biology: research priorities for the next decade, pp. 225-244, Island Press, Washington DC.

Prach, K., Bartha, S., Joyce, C.B., Pyšek, P., Van Diggelen, R. \& Wiegleb, G., 2001, 'The role of spontaneous vegetation succession in ecosystem restoration: a perspective', Applied Vegetation Science 4, 111-114. doi:10.1111/j.1654109X.2001.tb00241.x

Preston, F.W., 1948, 'The commonness and rarity of species', Ecology 29, 254-283. doi:10.2307/1930989

Redfern, J.V., Viljoen, P.C., Kruger, J.M. \& Getz, W.M., 2002, 'Biases in estimating population size from an aerial census: a case study in the Kruger National Park, South Africa', South African Journal of Science 98, 455-461.

Regan, H.M., Hierl, L.A., Franklin, J., Deutschman, D.H., Schmalbach, H.L., Winchell, C.S., et al., 2008, 'Species prioritization for monitoring and management in regional species conservation plans', Diversity and Distributions 14, 462-471. doi:10.1111/j.1472-4642.2007.00447.x

Rietkerk, M. \& Van de Koppel, J., 1997, 'Alternate stable states and threshold effects in semi-arid grazing systems', Oikos 79, 69-76. doi:10.2307/3546091 
Rodrigues, A.S.L., Andelman, S.J., Bakarr, M.I., Boitani, L., Brooks, T.M., Cowling, R.M., et al., 2004, 'Effectiveness of the global protected area network in R.M., et al., 2004, 'Efectiveness of the global protected area network in
representing species diversity', Nature 428, 640-643. doi:10.1038/nature02422, PMid:15071592

Rogers, K.H., 1997, 'Operationalizing ecology under a new paradigm: an African perspective', in S.T.A. Pickett, R.S. Ostfeld, M. Shachak \& G.E. Likens (eds.), The ecological basis of conservation: heterogeneity, ecosystems and biodiversity, pp. 60-80, Chapman \& Hall, New York.

Salafsky, N. \& Margoluis, R., 1999, 'Threat reduction assessment: a practical and cost-effective approach to evaluating conservation and development projects', Conservation Biology 13, 830-841. doi:10.1046/j.1523-1739.1999.98183.x

Sale, P.F., Cowen, R.K., Danilowicz, B.S., Jones, G.P., Kritzer, J.P. Lindeman, K.C., et al., 2005, 'Critical sciences gaps impede use of no-take fisheries reserves', Trends in Ecology and Evolution 20, 74-80. doi:10.1016/j.tree.2004.11.007

SANParks. See South African National Parks.

South African National Parks, 2007, Kruger National Park Biodiversity Management Programme: Strategic adaptive management, SANParks, Skukuza.

South African National Parks, 2010, South African National Parks: Resource use policy, SANParks, Pretoria.

Scoones, I., 1999, 'New ecology and the social sciences: what prospects for a fruitful engagement?', Annual Review of Anthropology 28, 479-507. doi:10.1146/ annurev.anthro.28.1.479

Sibly, R.M., Barker, D., Denham, M.C., Hone, J. \& Pagel, M., 2005, 'On the regulation of populations of mammals, birds, fish and insects', Science 309, 607-610. doi:10.1126/science.1110760, PMid:16040705

Simberloff, D., 1999, 'The role of science in the preservation of forest biodiversity', Forest Ecology and Management 115, 101-111. doi:10.1016/S0378$1127(98) 00391-0$

Slocombe, D.S., 1998, 'Lessons from experience with ecosystem-based management', Landscape and Urban Planning 40, 31-39. doi:10.1016/S0169-2046(97)00096-0

Smith, M.D. \& Knapp, A.K., 2003, 'Dominant species maintain ecosystem function with non-random species loss', Ecology Letters 6, 509-517. doi:10.1046/j.1461$0248.2003 .00454 x$

Society of Ecological Restoration, 2004, The SER Primer on Ecological Restoration, Society for Ecological Restoration Science and Policy Working Group, viewed 02 February2010, from http://www.ser.org/reading resources.asp

Spellerberg, I.F., 2005, Monitoring ecological change, Cambridge University Press, Cambridge. doi:10.1017/CBO9780511614699

Stringham, T.K., Krueger, W.C. \& Shave, P.L., 2003, 'State and transition modeling: An ecological process approach', Journal of Range Management 56, 106-113. doi: $10.2307 / 4003893$

Tompkins, E.L. \& Adger, W.N., 2004, 'Does adaptive management of natural resources enhance resilience to climate change?', Ecology and Society 9,10 , viewed 02 February 2010, from http://www.ecologyandsociety.org/vol9/iss2/art10/

Trollope, W.S.W., Potgieter, A.L.F., Biggs, H.C. \& Brockett, B., 1999, Report on the necessity, design and implementation of the Large Scale Herbivore Fire Interaction Research Experiment (LASHFIRE) in the Kruger National Park in South Africa, SANParks, Skukuza.
Van Aarde, R.J., Ferreira, S.M., Kritzinger, J.J., Van Dyk, P.J., Vogt, M. \& Wassenaar, T.D., 1996, 'An evaluation of habitat rehabilitation on coastal dune forests in northern KwaZulu-Natal, South Africa', Restoration Ecology 4, 334-345. doi:10.1111/ j.1526-100X.1996.tb00186.x

Van Aarde, R.J. \& Jackson, T.P., 2007, 'Megaparks for metapopulations: addressing the causes of locally high elephant numbers in southern Africa', Biological Conservation 134, 289-297. doi:10.1016/j.biocon.2006.08.027

Van Aarde, R.J., Jackson, T.P. \& Ferreira, S.M., 2006, 'Conservation science and elephant management in southern Africa', South African Journal of Science 102, 385-388.

Van Aarde, R.J., Whyte, I. \& Pimm, S.L., 1999, 'Culling and the dynamics of the Kruger National Park African elephant population', Animal Conservation 2, 287-294. doi:10.1111/j.1469-1795.1999.tb00075.x

Varghese, G., 2008, 'Public-private partnerships in South African national parks: rationale, benefits and lessons learned', in A. Spenceley (ed.), Responsible tourism: critical issues for conservation and development, pp 69-84, Earthscan Publications, London.

Walker, B.H., 1987, 'A general model of savanna structure and function', in B.H. Walker (ed.), Determinants of tropical savanna, pp. 1-12, ICSU Press, Miami.

Walsh, P.D., White, L.J.T., Mbina, C., Idiata, D., Mihindou, Y., Maisels, F., et al., 2001, 'Estimates of forest elephant abundance: projecting the relationship between precision and effort', Journal of Applied Ecology 38, 217-228. doi:10.1046/j.13652664.2001.00578.x

Wassenaar, T.D., Pimm, S.L., Van Aarde, R.J. \& Ferreira, S.M., 2005, 'Community convergence in disturbed sub-tropical dune forests', Ecology 86, 655-666. doi:10.1890/03-0836

Wassenaar, T.D., Ferreira, S.M. \& Van Aarde, R.J., 2007, 'Flagging aberrant sites and assemblages in restoration projects', Restoration Ecology 15, 68-76. doi:10.1111/ j.1526-100X.2006.00191.x

Weiner, J., 1992, 'Physiological limits to sustainable energy budgets in birds and mammals: ecological implications', Trends in Ecology and Evolution 7, 384-388. doi:10.1016/0169-5347(92)90009-Z

Westoby, M., Walker, B. \& Noy-Meir, I., 1989, 'Opportunistic management for rangelands not at equilibrium', Journal of Range Management 42, 266-274. doi:10.2307/3899492

Wilson, E.O., 1988, The current state of biological diversity, Biodiversity National Academy Press, Washington DC.

Woodroffe, R. \& Ginsberg, J.R., 1998, 'Edge effects and the extinction of populations inside protected areas', Science 280, 2126-2128. doi:10.1126/ science.280.5372.2126, PMid:9641920

Young, K.D., Ferreira, S.M. \& Van Aarde, R.J., 2009, 'The influence of increasing population size and vegetation productivity on elephant distribution in the Kruger National Park', Austral Ecology 34, 329-342. doi:10.1111/j.14429993.2009.01934.x 